\title{
The Effects of Lung Distension, Oxygenation, and Gestational Age on Fetal Behavior and Breathing Movements in Sheep ${ }^{1}$
}

\author{
SHABIH U. HASAN AND ANITA RIGAUX \\ Departments of Paediatrics and Reproductive Medicine Research Group, The University of Calgary, \\ Calgary, Alberta, Canada T2N $4 \mathrm{NI}$
}

\begin{abstract}
Lung distension with $100 \% \mathrm{O}_{2}$ at a continuous positive airway pressure of $30 \mathrm{~cm} \mathrm{H}_{2} \mathrm{O}$ may induce continuous fetal breathing movements (FBM) in sheep. The objectives of this study were 1 ) to investigate the relative roles of lung distension and oxygenation and 2) to test the hypothesis that FBM can be induced during labor, when normally they are greatly reduced or absent. We studied 13 chronically instrumented, unanesthetized fetal sheep between 128 and $144 \mathrm{~d}$ of gestation (term $=147 \pm$ $2 \mathrm{~d})$. Each fetus was instrumented to record sleep states, diaphragm electromyogram, blood pressure, arterial pH, and blood gas tensions. The fetal lungs were distended via an in situ endotracheal tube with four different concentrations of $\mathrm{O}_{2}(0,21,50$ and $100 \%)$ at a continuous positive airway pressure of 10,20 and $30 \mathrm{~cm} \mathrm{H}_{2} \mathrm{O}$ in a randomized order. No change in any recorded physiologic variable was observed at $129 \pm 1$ or $132 \pm 1$ d of gestation. At $135 \pm 1$ and $138 \pm 1 \mathrm{~d}$, in response to a continuous positive airway pressure of $30 \mathrm{~cm} \mathrm{H}_{2} \mathrm{O}$ and $100 \% \mathrm{O}_{2}, \mathrm{pH}$ decreased $(p=$ 0.0004 and 0.005 , respectively) and arterial $\mathrm{O}_{2}$ tension increased $(p=0.004$ and 0.02 , respectively). However, increases in 1 ) breathing time, 2) breathing time/lowvoltage electrocortical activity ratio, 3 ) duration of arousal, and 4) length of single breathing epochs were observed only at $138 \pm 1 \mathrm{~d}$. Lung distension with $\mathrm{N}_{2}$ resulted in a decrease in FBM. Six fetuses were studied during labor. Significant increase in total breathing time, stimulation of breathing during quiet sleep, and increased duration of arousal were observed with an increase in fetal arterial $\mathrm{O}_{2}$ tension. The onset of breathing always coincided with the onset of arousal. We conclude that fetal maturity, an increase in fetal arterial $\mathrm{O}_{2}$ tension, and a change in state from quiet sleep toward arousal are necessary conditions for the induction of FBM. (Pediatr Res 30: 193-201, 1991)
\end{abstract}

\section{Abbreviations}

BP, blood pressure

CPAP, continuous positive airway pressure

$\mathrm{EMG}_{N K}$, neck electromyogram

EOG, electro-oculogram

FBM, fetal breathing movements

ECoG, electrocorticogram

HV-ECoG, high-voltage ECoG or electrocortical activity

LV-ECoG, low-voltage ECoG or electrocortical activity

Received December 3, 1990; accepted April 8, 1991.

Correspondence and reprint requests: Dr. Shabih U. Hasan, Department of Paediatrics, Faculty of Medicine, University of Calgary, 3330 Hospital Drive N.W., Calgary, Alberta, Canada T2N 4N1.

Supported by the Foothills Hospital Research and Development Committee and the Alberta Children's Hospital Research Foundation.

'Presented in part at the Annual Meeting of the Society for Pediatric Research, May 7-11, 1990, Anaheim, CA.
ID, inner diameter

OD, outer diameter

$\mathrm{PaO}_{2}$, arterial $\mathrm{O}_{2}$ tension

$\mathrm{PaCO}_{2}$, arterial $\mathrm{CO}_{2}$ tension

Since the early studies of Dawes et al. (1), it has been known that fetal sheep make irregular, rapid, and episodic breathing movements (2). One of the many unique and vital changes occurring at birth is the establishment of continuous breathing. Mechanisms for the control of FBM or the initiation of continuous breathing at birth remain unknown. In sheep, during late gestation $(115-120 \mathrm{~d}$; term $=147 \pm 2 \mathrm{~d}), \mathrm{FBM}$ occupy $40 \%$ of the total time and occur normally only during LV-ECoG and are absent during HV-ECoG. Although the precise control mechanism for FBM has yet to be explained, FBM are susceptible to modulation. Isocapnic hypoxemia suppresses and normoxic hypercapnia stimulates FBM $(3,4)$; morphine, meclofenamate, indomethacin, pilocarpine, doxapram, aminophylline, caffeine, and 5-hydroxytryptophan stimulate, whereas general anesthetics, barbiturates, diazepam, and prostaglandin $E_{2}$ depress FBM $(2,5-8)$.

We have recently shown that distending fetal lungs with $100 \%$ $\mathrm{O}_{2}$ at a CPAP of approximately $30 \mathrm{~cm} \mathrm{H}_{2} \mathrm{O}$ may induce continuous FBM (9). However, the relative roles of distending pressure and oxygenation remain unknown. Nor is it known if these FBM can be induced during spontaneous onset of labor when normally these are absent or greatly reduced. Therefore, we designed a study 1 ) to investigate the relative roles of oxygenation and distending pressure by using various concentrations of $\mathrm{O}_{2}$ and different levels of distending pressures and 2) to test the hypothesis that FBM can be induced during spontaneous onset of labor.

\section{MATERIALS AND METHODS}

Animal preparation. We studied 13 fetal sheep between 128 and $144 \mathrm{~d}$ of gestation. Surgery was performed on time-dated, pregnant ewes of mixed breed between 124 and $132(127 \pm 2) \mathrm{d}$ of gestation using $4 \%$ halothane in $\mathrm{O}_{2}$ for induction of anesthesia and 1.5 to $2 \%$ for maintenance. After the skin was cleansed with iodine and $70 \%$ alcohol, the abdominal wall was opened by a midline incision using sterile technique. Avoiding major vessels, the uterine cavity was opened and the fetal head and neck were exteriorized. The uterine wall and fetal skin were brought together with several Babcock forceps to minimize loss of amniotic fluid. An incision was made at the upper dorsal part of the neck to tunnel four color-coded electrode wires to record ECoG, EOG, $\mathrm{EMG}_{N K}$, and diaphragm electromyogram. The electrodes were constructed from Teflon-coated stainless steel wire of which a $5.0-\mathrm{mm}$ segment at the end of each was scraped bare (Cooner 
Wire Co., Chatsworth, CA; AS 632). Each electrode was enveloped in polyvinyl tubing ( $1 \mathrm{~mm}$ ID and $2 \mathrm{~mm}$ OD; Portex, UK) and sealed with silicone of one of four different colors. To record the ECoG, a pair of electrodes was implanted bilaterally over the parietal area through two holes drilled in the fetal skull $2.5 \mathrm{~cm}$ apart and $4 \mathrm{~mm}$ behind the coronal sutures. These electrodes were fixed to the fetal skull using rubber pads and cyanoacrylate glue. To record the EOG, a silver-coated, oval-shaped electrode was embedded around the lateral rectus muscle of one eye through an incision made along the lateral bony orbital ridge; the reference electrode was implanted 3 to $4 \mathrm{~cm}$ below the orbit. $\mathrm{EMG}_{N K}$ electrodes were sutured in the lateral neck muscle $5 \mathrm{~cm}$ apart and $5 \mathrm{~cm}$ below the occiput. ECoG, EOG, and $\mathrm{EMG}_{N K}$ were used to define the fetal behavioral state. To place polyvinyl catheters ( $1 \mathrm{~mm}$ ID and $2 \mathrm{~mm}$ OD; Portex, Hythe, Kent, UK) in the fetal carotid artery and jugular vein, a 5- to $7-\mathrm{cm}$ ventral incision was made lateral to the trachea, starting just below the thyroid cartilage. The arterial catheter was used to monitor BP and draw blood samples for the analysis of $\mathrm{pH}$ and blood gas tensions; antibiotics and fluid were administered through the venous catheter. To apply CPAP to the fetal lungs, the trachea was exposed through the ventral neck incision and a $7.5-\mathrm{cm}$ endotracheal tube $(4.8 \mathrm{~mm}$ ID and $7.9 \mathrm{~mm}$ OD; Tygon, Norton Plastics, Akron, $\mathrm{OH}$ ) was inserted in the trachea and advanced for 5 to $6 \mathrm{~cm}$ through an incision made just below the thyroid cartilage. The endotracheal tube was transfixed (0-silk) to prevent dislodgement from the trachea and two (size 4 silk) threads were tied around the trachea to avoid air leaks that might occur during the lung distension experiments. The free end of the endotracheal tube was connected to a serrated $Y$ connector (polypropylene, $6.4 \mathrm{~mm}$ OD; Nalgene 6152, Sybron Corp., Rochester, NY), which in turn was connected to two polyvinyl tubes (4.8 $\mathrm{mm}$ ID and $7.9 \mathrm{~mm}$ OD, Tygon) that served as inspiratory and expiratory extensions of the endotracheal tube. This step was undertaken to minimize the dead space.

After removing the Babcock forceps, the fetus was further exteriorized to expose the lower chest area. A $5-\mathrm{cm}$ incision was made $3 \mathrm{~cm}$ above the lower subcostal margin to expose the right hemidiaphragm. Three s.c. tunneled electrode wires were implanted in the diaphragm and sutured securely along the 10th intercostal space. Although we used only two diaphragm electrode wires at any given time, the third wire was implanted to obtain the best possible combination of diaphragmatic signals. For common grounding purposes, a single reference electrode was also anchored firmly at the site of the initial tunneling. Two polyvinyl catheters were placed in the amniotic cavity by securing those at the back of the fetal head. One of the two amniotic catheters (2.4 mm ID and $4 \mathrm{~mm}$ OD; Tygon) was used for monitoring amniotic pressure and also for the electronic subtraction of fetal BP. The second amniotic catheter ( $4.8 \mathrm{~mm}$ ID and $7.9 \mathrm{~mm}$ OD; Tygon) was connected (perfectum adapters; Popper \& Sons, Inc., New Hyde Park, NY) to one of the endotracheal tube extensions to facilitate the tracheoamniotic fluid flow, whereas the second extension of the endotracheal tube remained plugged when no experiments were being conducted. Every effort was made to keep the exposed fetal parts covered to minimize heat loss. After the instrumentation was completed, the fetus was returned to the uterine cavity and all incisions were sewn in layers.

A polyvinyl catheter $(2.4 \mathrm{~mm}$ ID, $4 \mathrm{~mm} \mathrm{OD}$; Tygon) was placed in the jugular vein of the pregnant ewe for infusion of antibiotics and fluids. All fetal electrode wires and catheters were exteriorized through the maternal left flank and connected to the recording apparatus.

Postoperatively, the ewes had free access to water, hay, and alfalfa pellets. They received $10^{6}$ IU of benzylpenicillin and 80 $\mathrm{mg}$ of gentamicin i.v., and $20 \mathrm{mg}$ of gentamicin were injected into the amniotic cavity; the fetus received 75000 IU of benzylpenicillin and $10 \mathrm{mg}$ of gentamicin i.v. for $4 \mathrm{~d}$. The fetal and maternal vascular catheters were flushed with heparinized saline (heparin $10 \mathrm{IU} / \mathrm{mL}$ ) twice daily. To maintain patency, fetal arterial catheters were infused continuously with heparinized saline (heparin $1 \mathrm{IU} / \mathrm{mL}$ ) at a rate of $1.0 \mathrm{~mL} / \mathrm{h}$ (Harvard infusion pump, model no. 901; Harvard Apparatus Co., Inc., South Natick, MA).

Data acquisition and analysis. All the exteriorized fetal electrode wires were connected to the NeuroLog System (Medical Systems Corporation, Greenvale, NY). The amniotic pressure and fetal BP were recorded with Statham P23 ID pressure transducers (Gould Inc., Instrument Division, Cleveland, $\mathrm{OH}$ ). Subsequently, the appropriately amplified and filtered ECoG, $\mathrm{EOG}, \mathrm{EMG}_{N K}$, and diaphragm electromyogram signals were filtered such that the following respective frequency ranges were recorded: 0.5 to $40 \mathrm{~Hz}, 5$ to $40 \mathrm{~Hz}, 50 \mathrm{~Hz}$ to $1 \mathrm{kHz}$, and $50 \mathrm{~Hz}$ to $1 \mathrm{kHz}$. Amniotic pressure, BP, and electrophysiologic signals were recorded on an eight-channel recorder (Gould Brush 2800S) and on a video-cassette recorder using an eight-channel Neurocorder (DR-886) (Neurodata Instruments Corporation, New York, NY).

The analyses were done manually for each recorded minute and included measurements of 1 ) total time of a given experiment; 2) total breathing time (BT); 3) percentage of breathing time during total time (\% BT); 4) percentage of breathing time during LV-ECoG (\% BR LV); 5) percentage of breathing time during HV-ECoG (\% BR HV); 6) percentage of breathing time/ low voltage (\% BT/LV) (a value of more than $100 \%$ indicates presence of breathing during $\mathrm{HV}-\mathrm{ECOG}$ ); 7) percentage of eye movements during total time (\% EYE); 8) percentage of nuchal muscle activity during total time (\% NECK); 9 ) percentages of $\mathrm{LV}$ - and HV-ECoG (\% LV and \% $\mathrm{HV}$, respectively); 10 ) duration of arousal during the entire experiment in minutes; 11) longest single apneic episode in minutes; 12) longest single breathing epoch in minutes; 13) time lag to the onset of continuous breathing movements if present; 14) arterial $\mathrm{pH}$ and blood gas tensions; 15) hematocrit; 16) systolic, diastolic, and mean $\mathrm{BP}$; and 17) heart rate (bpm). Fetal heart rate was calculated from the peaks of systolic BP. The percentage of eye, nuchal and low and high voltage ECoG were measured to delineate the sleep states and were not the end points of this study.

Electrographic criteria were used to define active sleep, quiet sleep, and awake states $(10,11)$. Active sleep was defined by the simultaneous presence of LV-ECoG and eye movements, and absence of neck muscle tone; quiet sleep was defined by the simultaneous presence of HV-ECoG and neck muscle tone, and absence of eye movements. Fetal wakefulness was defined by the simultaneous presence of LV-ECoG, eye movements, and neck muscle tone $(10,11)$.

Experimental design. All experiments were done at least $3 \mathrm{~d}$ after surgery and only after fetal breathing had returned to the normal range for at least $24 \mathrm{~h}$. No experiments were done if the ewe appeared clinically unwell. In view of the diurnal variability in fetal breathing patterns, all experiments were started between 1100 and $1200 \mathrm{~h}$ and completed by $0400 \mathrm{~h}$, and lasted an average of $16 \mathrm{~h}$. In view of the length of the experiments, at least $3 \mathrm{~d}$ were allowed to elapse before another experiment was done on the same fetus. No other experiments were done on these fetal preparations.

Before each experiment, a control period was established: recordings were made for at least $3 \mathrm{~h}$ showing both LV- and $\mathrm{HV}$ $\mathrm{ECoG}$, which normally coincided with periods of breathing and nonbreathing, respectively. After tracheal suction was done through one of the two loops of the endotracheal tube extension, the fetal lungs were distended with $0 \% \mathrm{O}_{2}\left(100 \% \mathrm{~N}_{2}\right)$ for uniform distension at a CPAP of $30 \mathrm{~cm} \mathrm{H}_{2} \mathrm{O}$; this pressure was achieved in increments of $10 \mathrm{~cm} \mathrm{H}_{2} \mathrm{O}$ to avoid sudden increases in intrathoracic pressure. This particular step in the protocol was added to optimize uniform lung distension and minimize the confounding variable of lower CPAP at the outset of the experiments. Thereafter, the fetal lungs were distended with four concentrations of $\mathrm{O}_{2}(0,21,50$, and $100 \%)$ at three levels of CPAP 
(10,20 and $30 \mathrm{~cm} \mathrm{H} \mathrm{H}_{2} \mathrm{O}$ ) in a randomized order, yielding 12 subsets for each experiment. A given amount of pressure and/or $\mathrm{O}_{2}$ concentration was maintained for at least two complete cycles of electrocortical activity (one cycle = one cycle of LV-ECoG plus one cycle of HV-ECoG). Various levels of CPAP were achieved using a Baby Bird Ventilator (Bird Corp, Palm Springs, CA; model no. 5900). All changes in CPAP and/or $\mathrm{O}_{2}$ concentrations were made only during HV-ECoG to maintain consistency and to avoid the effects of FBM that normally occur during LV-ECoG. $\mathrm{O}_{2}$ concentration was adjusted with a Baby Bird $\mathrm{O}_{2}$ blender and monitored by an $\mathrm{O}_{2}$ analyzer (Hudson Ventronics; model no. $5584 \mathrm{EC}$ ). Because a change in fetal temperature may stimulate breathing $(12,13)$, the inspired gases were humidified and heated to $39.5^{\circ} \mathrm{C}$ before administration (Fisher \& Paykel Ltd., servo-controlled model no. 328 humidifier) (Allied Products, Medical Division, Panmure, Auckland, New Zealand).

Six ewes were studied during labor. No attempt was made either to postpone or to induce labor. Because intrauterine pressure rises during labor, CPAP was gradually increased to 40 , 50 , and $60 \mathrm{~cm} \mathrm{H}_{2} \mathrm{O}$ to raise $\mathrm{PaO}_{2}$. Furthermore, during labor, due to time constraints, it was not always possible to use the lower pressures $\left(10\right.$ and $\left.20 \mathrm{~cm} \mathrm{H}_{2} \mathrm{O}\right)$. However, at higher pressures, $\mathrm{N}_{2}$ was always added to the experimental protocol.

Arterial $\mathrm{pH}$ and blood gas tensions were determined on $0.3-$ $\mathrm{mL}$ aliquots during the control period, before tracheal suction, after tracheal suction, and during both LV- and HV-ECoG states. If stimulation of breathing occurred, frequent blood gas determinations were done. Hematocrit was checked before and during the experiment, and blood was replaced as required. The blood samples were kept on ice until the time of analysis and the temperature of the blood gas analyzer was modified to $39.5^{\circ} \mathrm{C}$ (Instrumentation Laboratory System, Lexington, MA).

These studies were approved by the Animal Care Committee of the University of Calgary.

Statistical analysis. The fetuses were divided into five groups: 1) $129 \pm 1 \mathrm{~d}, 2) 132 \pm 1 \mathrm{~d}, 3) 135 \pm 1 \mathrm{~d}, 4) 138 \pm 1 \mathrm{~d}$, and 5) during labor. The analyses were done using multivariate analysis of variance based on two-factor experiments with repeated measurements on one factor $(14,15)$. Comparisons were made between control and 12 experimental conditions for each recorded variable. Similarly, comparisons were also made between the various gestational ages. The data in the text are presented as the mean $\pm \mathrm{SD}$, and a $p$ value of less than 0.05 was considered to be significant.

\section{RESULTS}

Gestational age $129 \pm 1 \mathrm{~d}$. Three fetuses were studied in this gestational age group. There were no statistically significant differences in any of the variables. In one fetus, $\mathrm{PaO}_{2}$ increased from 2.91 to $4.53 \mathrm{kPa}(21.8$ to 34 torr; 1 torr $=0.1333 \mathrm{kPa})$ at a CPAP of $30 \mathrm{~cm} \mathrm{H}_{2} \mathrm{O}$ and $100 \% \mathrm{O}_{2}$ with no changes in any of the cardiorespiratory or behavioral responses (Fig. 1).

Gestational age $132 \pm 1 \mathrm{~d}$. Eight fetuses were studied in this group. There were no significant changes at a CPAP of 10 or 20 $\mathrm{cm} \mathrm{H}_{2} \mathrm{O}$ at any $\mathrm{O}_{2}$ concentration. However, when the lungs were distended with $100 \% \mathrm{O}_{2}$ at a pressure of $30 \mathrm{~cm} \mathrm{H}_{2} \mathrm{O}$, arterial $\mathrm{pH}$ decreased to $7.29 \pm 0.7$ and $\mathrm{PaO}_{2}$ increased to $8.77 \pm 7.34 \mathrm{kPa}$ $(65.8 \pm 55.1$ torr) from the control values of $7.36 \pm 0.04$ and $3.23 \pm 0.45 \mathrm{kPa}(24.2 \pm 3.4$ torr $)$, respectively $(p=0.06$ and 0.16 , respectively). The large $\mathrm{SD}$ in $\mathrm{pH}$ and $\mathrm{PaO}_{2}$ resulted from the fact that $\mathrm{PaO}_{2}$ increased in only three of eight fetuses. The $\mathrm{pH}$ in these fetuses decreased from control values of 7.37, 7.33, and 7.39 to 7.28, 7.19, and 7.29; $\mathrm{PaO}_{2}$ increased from 3.29, 3.87, and $3.07 \mathrm{kPa}$ to $12.45,21.19$, and $12.32 \mathrm{kPa}(24.7,29$, and 23 torr to $93.4,159$, and 92.4 torr) during control and experimental conditions, respectively. $\mathrm{PaCO}_{2}$ remained unchanged. However, there were no significant changes in any of the breathing or behavioral responses. For example, among the three oxygenated fetuses, breathing movements occurred for $52.5,48.2$, and $49.7 \%$
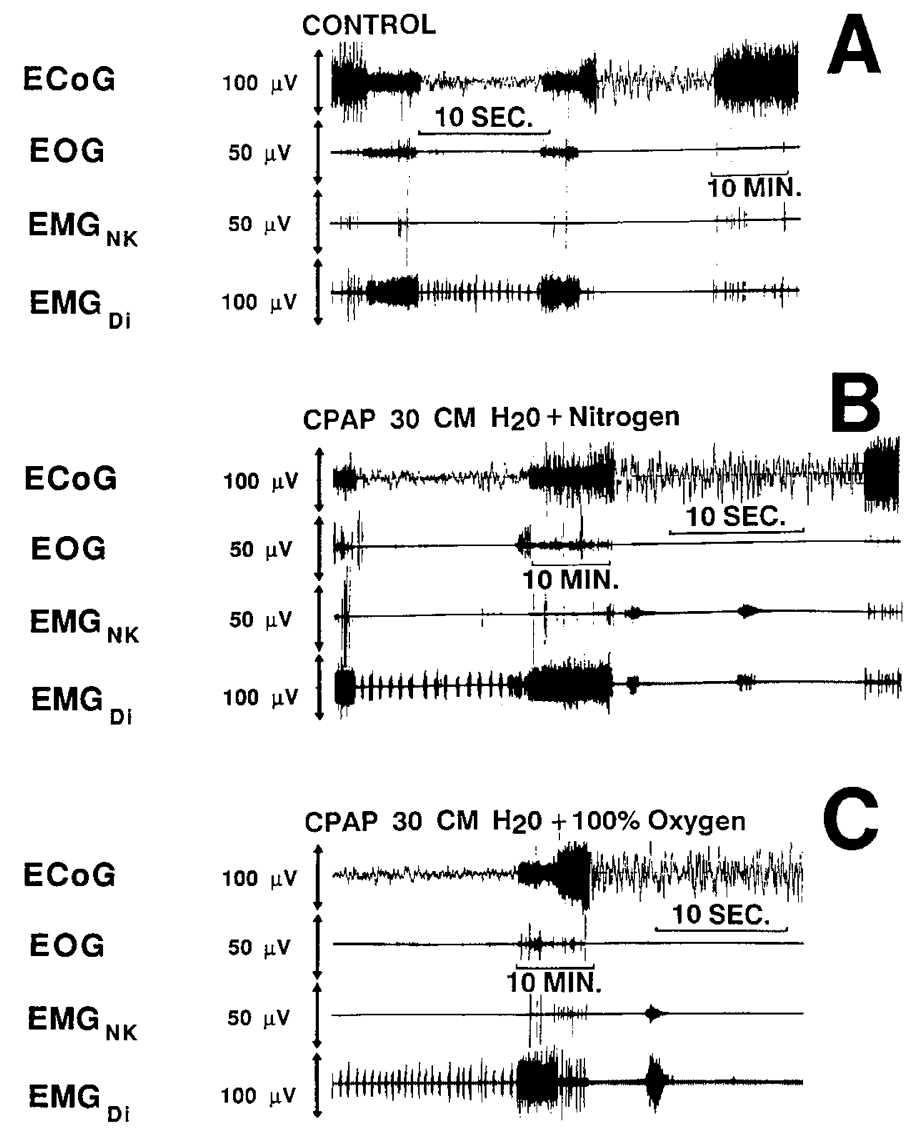

Fig. 1. Effects of lung distension at $130 \mathrm{~d}$ of gestation. Representative tracing showing the control period $(A)$ and the effects of lung distension with CPAP of $30 \mathrm{~cm} \mathrm{H}_{2} \mathrm{O}$ with nitrogen and with $100 \% \mathrm{O}_{2}$. Note that lung distension at this gestational age with $0 \% \mathrm{O}_{2}$ (nitrogen) $(B)$ or with $100 \% \mathrm{O}_{2}(C)$ had no effect on behavior or FBM.

of the total time under control conditions and 48, 25.4, and $43 \%$ during experimental conditions, suggesting that there was no association between an increase in $\mathrm{PaO}_{2}$ and the incidence of breathing movements at this gestational age. All fetal breathing activity took place during LV-ECoG. There were no statistically significant changes in $\mathrm{BP}$ or heart rate at any CPAP or $\mathrm{O}_{2}$ concentration.

Gestational age $135 \pm 1 \mathrm{~d}$. Results from the six fetuses in this group are summarized in Table 1 . In all six fetuses, statistically significant increases in $\mathrm{PaO}_{2}$ and $\mathrm{PaCO}_{2}$ and a decrease in $\mathrm{pH}$ were observed at a CPAP of $30 \mathrm{~cm} \mathrm{H}_{2} \mathrm{O}$ and $100 \% \mathrm{O}_{2}$. The $\mathrm{PaO}_{2}$ and $\mathrm{PaCO}_{2}$ increased from $2.73 \pm 0.61$ and $5.33 \pm 0.60$ to 15.30 \pm 5.76 and $6.68 \pm 1.37 \mathrm{kPa}(20.5 \pm 4.6$ and $40 \pm 4.5$ to 114.8 \pm 43.2 and $50.1 \pm 10.3$ torr), respectively, and $\mathrm{pH}$ decreased from $7.34 \pm 0.03$ to $7.25 \pm 0.04(p=0.004,0.01$, and 0.0004 respectively). However, once again, all measured cardiorespiratory and behavioral responses remained unchanged. Only one of six fetuses manifested 24.5 and $16.9 \%$ of its breathing during HV-ECoG at a CPAP of $20 \mathrm{~cm}$ in conjunction with 50 and $100 \%$ oxygen, respectively. The $\mathrm{PaO}_{2}$ in this fetus increased from 2.66 to $8.80 \mathrm{kPa}$ ( 20 to 66 torr), $\mathrm{pH}$ decreased from 7.28 to 7.25 and $\mathrm{PaCO}_{2}$ remained constant at 6.40 and $6.28 \mathrm{kPa}(48$ and 47.1 torr) during control and experimental conditions, respectively. The lag time from changing the $\mathrm{O}_{2}$ mixture to the onset of breathing was 5.4 and $15.2 \mathrm{~min}$. The same fetus also breathed during lung distension with $100 \% \mathrm{O}_{2}$ at a CPAP of $30 \mathrm{~cm}$. On this occasion, the $\mathrm{PaO}_{2}$ was $9.60 \mathrm{kPa}$ (72 torr), $\mathrm{pH}$ decreased to 7.23 , and $\mathrm{PaCO}_{2}$ increased to $6.80 \mathrm{kPa}(51$ torr); $37.6 \%$ of the total breathing occurred during HV-ECoG.

At this gestational age, the longest single apneic episode remained unchanged, whereas the longest single breathing epoch was significantly decreased when the lungs were distended with 
Table 1. Cardiorespiratory and behavioral responses to lung distension and oxygenation in six fetuses at $135 \pm 1$ d gestational age*

\begin{tabular}{|c|c|c|c|c|c|c|c|c|c|c|c|c|c|}
\hline \multirow[b]{3}{*}{ Variable } & \multirow[b]{3}{*}{ Control } & \multicolumn{12}{|c|}{ CPAP level $\left(\mathrm{cm} \mathrm{H}_{2} \mathrm{O}\right)$} \\
\hline & & \multicolumn{4}{|c|}{10} & \multicolumn{4}{|c|}{20} & \multicolumn{4}{|c|}{30} \\
\hline & & $100 \% \mathrm{~N}_{2}$ & $21 \% \mathrm{O}_{2}$ & $50 \% \mathrm{O}_{2}$ & $100 \% \mathrm{O}_{2}$ & $100 \% \mathrm{~N}_{2}$ & $21 \% \mathrm{O}_{2}$ & $50 \% \mathrm{O}_{2}$ & $100 \% \mathrm{O}_{2}$ & $100 \% \mathrm{~N}_{2}$ & $21 \% \mathrm{O}_{2}$ & $50 \% \mathrm{O}_{2}$ & $100 \% \mathrm{O}_{2}$ \\
\hline$\%$ BT & $42.8 \pm 11.9$ & $19.8 \pm 22.5$ & $31.7 \pm 22.3$ & $24.6 \pm 23.8$ & $29.8 \pm 21.1$ & $18.3 \pm 22.7$ & $45.7 \pm 28.8$ & $44.7 \pm 18.5$ & $40.4 \pm 20.0$ & $19.2 \pm 13.6 \dagger$ & $40.0 \pm 20.3$ & $41.6 \pm 21.0$ & $44.6 \pm 29.5$ \\
\hline$\% \mathrm{BT} / \mathrm{LV}$ & $88.9 \pm 7.9$ & $41.8 \pm 40.0$ & $66.3 \pm 46.6$ & $52.5 \pm 50.3$ & $71.8 \pm 13.4$ & $40.8 \pm 48.8$ & $79.4 \pm 6.2$ & $79.2 \pm 26.8$ & $78.9 \pm 36.0$ & $43.7 \pm 29.0 \dagger$ & $89.9 \pm 43.4$ & $75.0 \pm 43.5$ & $81.2 \pm 38.2$ \\
\hline $\begin{array}{l}\text { Dur. arousal } \\
\text { (min) }\end{array}$ & $3.4 \pm 6.0$ & $0.2 \pm 0.4$ & $1.2 \pm 1.2$ & $1.3 \pm 2.7$ & $0.3 \pm 0.7$ & $1.1 \pm 1.4$ & $0.6 \pm 1.2$ & $1.8 \pm 2.1$ & $8.6 \pm 15.5$ & $1.0 \pm 1.4$ & $2.3 \pm 2.9$ & $4.8 \pm 4.9$ & $16.1 \pm 21.9$ \\
\hline $\begin{array}{l}\text { Long. ap. prd. } \\
\text { (min) }\end{array}$ & $26.2 \pm 6.8$ & $19.9 \pm 8.3$ & $23.9 \pm 15.3$ & $44.6 \pm 26.4$ & $17.0 \pm 10.6$ & $27.5 \pm 13.1$ & $20.6 \pm 11.9$ & $13.6 \pm 11.4$ & $15.5 \pm 7.2$ & $26.4 \pm 11.1$ & $17.8 \pm 6.1$ & $20.5 \pm 9.6$ & $24.0 \pm 18.4$ \\
\hline $\begin{array}{l}\text { Long. br. prd. } \\
\text { (min) }\end{array}$ & $27.9 \pm 8.0$ & $5.1 \pm 5.3 \ddagger$ & $10.0 \pm 8.5$ & $12.2 \pm 8.2$ & $10.1 \pm 7.1$ & $6.6 \pm 7.7 \ddagger$ & $20.2 \pm 6.9$ & $15.7 \pm 14.2$ & $22.8 \pm 15.5$ & $7.8 \pm 3.8 \ddagger$ & $14.5 \pm 6.7$ & $18.2 \pm 9.5$ & $19.7 \pm 13.1$ \\
\hline pH & $7.34 \pm 0.03$ & $7.33 \pm 0.05$ & $7.35 \pm 0.03$ & $7.34 \pm 0.06$ & $7.32 \pm 0.06$ & $7.33 \pm 0.07$ & $7.33 \pm 0.06$ & $7.33 \pm 0.05$ & $7.32 \pm 0.07$ & $7.32 \pm 0.04$ & $7.31 \pm 0.03 \ddagger$ & $7.32 \pm 0.05$ & $7.25 \pm 0.04 \S$ \\
\hline $\begin{array}{l}\mathrm{PaCO}_{2}(\mathrm{kPa}) \| \\
\mathrm{PaO}_{2}(\mathrm{kPa})\end{array}$ & $\begin{array}{l}5.3 \pm 0.6 \\
2.7 \pm 0.6\end{array}$ & $\begin{array}{l}5.1 \pm 0.8 \\
2.5 \pm 0.7\end{array}$ & $\begin{array}{l}4.9 \pm 0.9 \\
29+0.9\end{array}$ & $5.5 \pm 0.5$ & $5.0 \pm 0.7$ & $5.5 \pm 1.4$ & $5.4 \pm 0.7$ & $5.4 \pm 0.5$ & $5.3 \pm 0.9$ & $5.3 \pm 0.8$ & $5.3 \pm 0.7$ & $5.6 \pm 0.4$ & $6.7 \pm 1.4 \dagger$ \\
\hline $\begin{array}{l}\mathrm{PaO}_{2}(\mathrm{kPa}) \\
\mathrm{HCO}_{3}\end{array}$ & $\begin{array}{r}2.7 \pm 0.6 \\
20.7 \pm 1.1\end{array}$ & $\begin{aligned} 2.5 & \pm 0.7 \\
20.0 & \pm 6.0\end{aligned}$ & $2.9 \pm 0.9$ & $2.7 \pm 0.6$ & $2.6 \pm 0.4$ & $2.5 \pm 0.6$ & $2.7 \pm 0.5$ & $3.6 \pm 2.6$ & $4.1 \pm 2.9$ & $2.7 \pm 0.6$ & $3.0 \pm 0.7$ & $4.1 \pm 2.3$ & $15.3 \pm 5.8 \S$ \\
\hline $\begin{array}{l}\mathrm{HCO}_{3} \\
\quad(\mathrm{mmol} / \mathrm{L})\end{array}$ & $20.7 \pm 1.1$ & $20.0 \pm 6.0$ & $19.9 \pm 3.3$ & $21.6 \pm 2.5$ & $19.7 \pm 3.9$ & $20.7 \pm 3.5$ & $21.0 \pm 4.2$ & $20.6 \pm 2.3$ & $20.6 \pm 3.9$ & $20.1 \pm 2.2$ & $20.1 \pm 3.0$ & $21.4 \pm 2.4$ & $21.2 \pm 3.4$ \\
\hline $\begin{array}{l}\mathrm{BD} / \mathrm{BE} \\
(\mathrm{mmol} / \mathrm{L})\end{array}$ & $-3.4 \pm 1.0$ & $-4.1 \pm 3.8$ & $-3.5 \pm 2.7$ & $-2.7 \pm 3.4$ & $-4.8 \pm 3.9$ & $-3.5 \pm 3.3$ & $-3.3 \pm 4.5$ & $-3.5 \pm 2.8$ & $-3.5 \pm 3.9$ & $-4.2 \pm 1.8$ & $-4.4 \pm 2.8$ & $-3.0 \pm 3.0$ & $-4.9 \pm 2.6$ \\
\hline $\begin{array}{l}\text { Syst BP } \\
\text { (mm Hg) }\end{array}$ & $60.0 \pm 7.7$ & $63.4 \pm 8.6$ & $64.5 \pm 10.5$ & $64.6 \pm 3.9$ & $62.4 \pm 9.2$ & $60.8 \pm 11.4$ & $62.0 \pm 10.0$ & $61.2 \pm 9.6$ & $59.7 \pm 8.9$ & $64.8 \pm 7.1$ & $63.0 \pm 5.4$ & $64.0 \pm 4.9$ & $67.2 \pm 5.6$ \\
\hline $\begin{array}{l}\text { Diast BP } \\
(\mathrm{mm} \mathrm{Hg})\end{array}$ & $41.7 \pm 6.7$ & $43.2 \pm 9.1$ & $45.5 \pm 9.6$ & $43.2 \pm 8.3$ & $43.2 \pm 9.5$ & $42.6 \pm 10.8$ & $43.8 \pm 9.0$ & $43.2 \pm 7.0$ & $40.7 \pm 10.3$ & $43.8 \pm 7.9$ & $43.8 \pm 7.4$ & $44.3 \pm 5.7$ & $45.8 \pm 4.8$ \\
\hline $\begin{array}{c}\text { Mean BP } \\
\text { (mm Hg) }\end{array}$ & $47.8 \pm 6.7$ & $49.9 \pm 8.5$ & $51.8 \pm 9.3$ & $50.3 \pm 6.3$ & $49.6 \pm 9.1$ & $48.7 \pm 10.9$ & $49.9 \pm 9.1$ & $49.2 \pm 7.6$ & $47.0 \pm 9.7$ & $50.8 \pm 7.4$ & $50.2 \pm 6.4$ & $50.9 \pm 5.1$ & $52.9 \pm 4.8$ \\
\hline $\begin{array}{l}\text { Heart rate } \\
(\mathrm{bpm})\end{array}$ & $162.0 \pm 21.0$ & $164.0 \pm 22.0$ & $170.0 \pm 40.0$ & $137.0 \pm 21.0$ & $140.0 \pm 10.0$ & $155.0 \pm 18.0$ & $147.0 \pm 31.0$ & $151.0 \pm 27.0$ & $156.0 \pm 32.0$ & $146.0 \pm 20.0$ & $164.0 \pm 29.0$ & $157.0 \pm 28.0$ & $147.0 \pm 20.0$ \\
\hline
\end{tabular}

* Values are mean \pm SD. \% BT, percentage of breathing time; \% BT/LV, ratio of breathing time during LV-ECoG; Dur. arousal, duration of arousal; Long. ap. prd., longest apneic period; Long. br. prd., longest breathing period; $\mathrm{BD} / \mathrm{BE}$, base deficit/base excess; Syst BP, Systolic blood pressure; and Diast BP, Diastolic blood pressure.

$\dagger p \leq 0.02$.
$\ddagger p \leq 0.05$.

$\S p \leq 0.01$.

$\|$ torr $=0.1333 \mathrm{kPa}$. 
$\mathrm{N}_{2}$ at any given CPAP; however, the percentage of breathing time was only decreased at a CPAP of $30 \mathrm{~cm}$ and $100 \% \mathrm{~N}_{2}(p=$ 0.01 ; Table 1).

Gestational age $138 \pm d$. Six fetuses were studied in this group. The results are summarized in Table 2 . Breathing time and duration of arousal significantly increased in response to lung distension with $100 \% \mathrm{O}_{2}$ at a CPAP of $30 \mathrm{~cm} \mathrm{H}_{2} \mathrm{O}(p=0.04$ and 0.03 , respectively). There was a significant increase in $\mathrm{PaO}_{2}$ and a decrease in $\mathrm{pH}$ and base excess. Lung distension with $\mathrm{N}_{2}$ at a CPAP of 20 and $30 \mathrm{~cm} \mathrm{H} \mathrm{H}_{2} \mathrm{O}$ decreased the percentage of total breathing time. The longest apneic episode decreased at a CPAP of $30 \mathrm{~cm}$ and 50 and $100 \% \mathrm{O}_{2}$, but did not reach statistical significance $(p=0.13)$. The single longest breathing episode decreased at 10 and $20 \mathrm{~cm} \mathrm{H}_{2} \mathrm{O}$ with most inspired $\mathrm{O}_{2}$ concentrations. Cardiovascular responses remained unchanged (Table 2). In four of six fetuses, lung distension with $100 \% \mathrm{O}_{2}$ at a CPAP of $30 \mathrm{~cm} \mathrm{H} \mathrm{H}_{2} \mathrm{O}$ resulted in the induction of breathing, which remained continuous until either CPAP or the $\mathrm{O}_{2}$ concentration was brought to a lower level. In these four fetuses, breathing time, breathing time/LV-ECoG ratio, duration of arousal, longest single breathing epoch, $\mathrm{PaO}_{2}$, and base deficit significantly increased from control values of $32.5 \pm 10.9 \%, 70.7$ $\pm 24.1 \%, 0 \pm 0 \mathrm{~min}, 18.4 \pm 8.2 \mathrm{~min}, 2.8 \pm 0.7 \mathrm{kPa}$, and $3.8 \pm$ $1.8 \mathrm{mmol} / \mathrm{L}$ to $100 \pm 0 \%, 163.4 \pm 11.43 \%, 27 \pm 7.8 \mathrm{~min}, 44.4$ $\pm 11.8 \mathrm{~min}, 31.6 \pm 9.5 \mathrm{kPa}$, and $6.3 \pm 2.2 \mathrm{mmol} / \mathrm{L}$, respectively, during lung distension with $100 \% \mathrm{O}_{2}$ at $30 \mathrm{~cm} \mathrm{H}_{2} \mathrm{O}(p=0.001$, $0.02,0.006,0.004,0.01$, and 0.025 , respectively), whereas $\mathrm{pH}$ and longest apneic episode decreased from $7.28 \pm 0.04$ and 39.3 $\pm 23.5 \mathrm{~min}$ to $7.22 \pm 0.03$ and $0 \pm 0 \mathrm{~min}$, respectively $(p=0.02$ and 0.04 , respectively). Percentages of breathing during $\mathrm{HV}$ ECoG under control and experimental conditions were $0 \pm 0$ and $26.1 \pm 18$, respectively $(p=0.04)$. The $\mathrm{PaCO}_{2}$ did not change $(p=0.56)$. Also, cardiovascular responses remained unchanged. The lag time varied from 9 to $30 \mathrm{~min}(9.9 \pm 14.1 \mathrm{~min})$. The onset of arousal always coincided with the onset of breathing and was significantly longer than observed during control periods $(p=0.03$; Fig. 2). There was an inverse correlation between $\mathrm{pH}$ and $\mathrm{PaO}_{2}(p=0.005)$.

Labor. Six fetuses were studied during spontaneous onset of labor. All were delivered within $12 \mathrm{~h}$. Two fetuses had only modest increases in $\mathrm{PaO}_{2}$ - to 5.4 and $6.6 \mathrm{kPa}$ from 2.0 and 2.1 $\mathrm{kPa}$, respectively (to 40.3 and 49.6 torr from 15.0 and 16.7 torr, respectively). Both were delivered within $4 \mathrm{~h}$. The percentage of breathing time among all six fetuses was $7.8 \pm 5.6$ and $42.9 \pm$ 33.7 during control and experimental conditions, respectively $(p$ $=0.03$ ). No breathing was noted during $\mathrm{HV}-\mathrm{ECoG}$ under resting conditions, whereas $38.23 \pm 15.4 \%$ of the total breathing occurred during HV-ECoG under experimental conditions. The arterial pH decreased from $7.28 \pm 0.10$ to $7.26 \pm 0.07, \mathrm{PaO}_{2}$ increased from $2.4 \pm 0.6$ to $20.8 \pm 14.5 \mathrm{kPa}$, and $\mathrm{PaCO}_{2}$ remained unchanged at $5.9 \pm 0.4$ and $6.4 \pm 0.7$ under control and experimental conditions, respectively $(p=0.04,0.03$, and 0.09 , respectively). The increase in $\mathrm{PaO}_{2}$ was achieved with a CPAP of $30 \mathrm{~cm} \mathrm{H} \mathrm{H}_{2} \mathrm{O}$ in two fetuses and with $40,45,55$, and $60 \mathrm{~cm} \mathrm{H}_{2} \mathrm{O}$ in the remaining four. Once again, fetal arousal coincided with the onset of breathing (Fig. 3). The breathing movements and $\mathrm{PaO}_{2}$ gradually decreased as the frequency and amplitude of uterine contractions increased. Systolic, diastolic, and mean BP $(\mathrm{mm} \mathrm{Hg})$ were $71 \pm 13$ and $69 \pm 19,46 \pm 13$ and $44 \pm 12$, and $54 \pm 13$ and $53 \pm 13$ under control and experimental conditions, respectively ( $p=0.74,0.46$, and 0.56 , respectively). Heart rate was $157 \pm 13$ and $146 \pm 16(p=0.35)$ under control and experimental conditions, respectively.

\section{DISCUSSION}

This study provides new evidence that fetal arousal and stimulation of FBM during quiet sleep may be induced by lung distension and an increase in fetal $\mathrm{PaO}_{2}$. These breathing and behavioral responses are critically dependent on fetal maturity, an association not observed in the previous study (9). Furthermore, FBM can be stimulated during both LV- and HV-ECoG during labor when, normally, FBM are either absent or are greatly reduced (16).

Isocapnic hypoxemia suppresses fetal breathing through a central mechanism, inasmuch as transection at midcollicular level as well as lateral pontine lesions leads to disinhibition of breathing during hypoxia (17-19). Therefore, it is conceivable that an increase in $\mathrm{PaO}_{2}$ above the normal fetal level disinhibits the central inhibitory mechanism, which is set for the normal fetal $\mathrm{PaO}_{2}$ range. However, we did not observe disinhibition of breathing during HV-ECoG until $136 \mathrm{~d}$ of gestation, even though this central inhibitory mechanism is operative in fetuses younger as well as older than $136 \mathrm{~d}$. Because we did not investigate the threshold range of $\mathrm{PaO}_{2}$ for stimulation of breathing, we cannot determine if the lack of stimulation in young fetuses was due to neural immaturity or if a very high level of $\mathrm{PaO}_{2}$ (which was not achieved in the younger fetuses) is required to stimulate breathing. Current knowledge would suggest that the former hypothesis is correct (20).

An increase in fetal $\mathrm{PaO}_{2}$ has been produced by several investigators either by placing the ewe in a hyperbaric chamber or by intermittent positive pressure ventilation of the fetal lungs (21$25)$. However, breathing movements were not measured in any of these studies. Blanco et al. (26) were able to oxygenate the fetus by in utero ventilation but no change in FBM was observed. The discrepancy between our results and those of Blanco et al. was probably due to the younger gestational age of their fetuses $(120-127 \mathrm{~d})$; also, we did not notice an increase in FBM until after $134 \mathrm{~d}$ of gestation. It is not known if there is a graded breathing response to various levels of arterial $\mathrm{PaO}_{2}$ or if there is a threshold range of $\mathrm{PaO}_{2}$ at which arousal and/or stimulation of FBM occur. An interesting observation was the wide variability in the lag time from the change of $\mathrm{O}_{2}$ concentration to the onset of arousal and breathing. This lag time may represent the time taken for the $\mathrm{PaO}_{2}$ to increase to a level that is critical for the induction of arousal and/or breathing. An increase in $\mathrm{O}_{2}$ tension may lead to cerebral vasoconstriction and, consequently, a decreased cerebral blood flow (27). Such changes in cerebral circulation could give rise to a widened arteriovenous $\mathrm{CO}_{2}$ difference, resulting in a rise in sagittal sinus and tissue $\mathrm{PCO}_{2}$, and an increase in fetal $\mathrm{PCO}_{2}$ is well known to stimulate $\mathrm{FBM}(2,3,5)$.

We observed that an increase in fetal $\mathrm{PaO}_{2}$, with or without an increase in $\mathrm{PaCO}_{2}$, and in the presence or absence of continuous FBM, was associated with a significant decrease in arterial $\mathrm{pH}$. This change in metabolic milieu might have been due to alterations in fetal cardiovascular dynamics and fetoplacental blood flow induced by CPAP. An increase in intrathoracic pressure induced by CPAP would be more profound in relatively mature fetuses due to an increase in pulmonary compliance. This decrease in $\mathrm{pH}$ (metabolic acidemia) might have resulted from decreased cardiac output, leading to poor tissue perfusion and impaired $\mathrm{O}_{2}$ delivery to meet the fetal metabolic demands (anerobic metabolism), and from decreased umbilical and renal blood flows, leading to an accumulation of metabolic end products (28, 29). A decrease in fetal tissue $\mathrm{PO}_{2}$ in response to increased $\mathrm{PaO}_{2}$ has been reported by Towell et al. (30). The decreased umbilical blood flow might result from attenuated venous return due either to increased intrathoracic pressure or to the direct contractile effects of $\mathrm{O}_{2}$ on the umbilical cord as suggested by Lewis (31). Because the decrease in $\mathrm{pH}$ was not observed when fetal lungs were distended with $\mathrm{N}_{2}$ or gas mixtures containing less than $100 \% \mathrm{O}_{2}$, the decrease in $\mathrm{pH}$ cannot be attributed exclusively to an impairment of cardiac output. Although the effects of in utero CPAP on fetal cardiovascular dynamics have not been studied, the effects of in utero intermittent positive pressure ventilation are well documented $(24,25)$. Teitel et al. $(25)$ did not observe a decrease in $\mathrm{pH}$ with an increase in $\mathrm{PaO}_{2}$ until the umbilical cord was occluded, but the observations of Blanco et al. (26) were similar to ours. Metabolic acidemia is known to stimulate FBM, 
Table 2. Cardiorespiratory and behavioral responses to lung distension and oxygenation in six fetuses at $138 \pm 1$ d gestational age*

\begin{tabular}{|c|c|c|c|c|c|c|c|c|c|c|c|c|c|}
\hline \multirow[b]{3}{*}{ Variable } & \multirow[b]{3}{*}{ Control } & \multicolumn{12}{|c|}{ CPAP level $\left(\mathrm{cm} \mathrm{H}_{2} \mathrm{O}\right)$} \\
\hline & & \multicolumn{4}{|c|}{10} & \multicolumn{4}{|c|}{20} & \multicolumn{4}{|c|}{30} \\
\hline & & $100 \% \mathrm{~N}_{2}$ & $21 \% \mathrm{O}_{2}$ & $50 \% \mathrm{O}_{2}$ & $100 \% \mathrm{O}_{2}$ & $100 \% \mathrm{~N}_{2}$ & $21 \% \mathrm{O}_{2}$ & $50 \% \mathrm{O}_{2}$ & $100 \% \mathrm{O}_{2}$ & $100 \% \mathrm{~N}_{2}$ & $21 \% \mathrm{O}_{2}$ & $50 \% \mathrm{O}_{2}$ & $100 \% \mathrm{O}_{2}$ \\
\hline$\% \mathrm{BT}$ & $34.9 \pm 9.5$ & $13.3 \pm 19.5$ & $22.7 \pm 28.5$ & $12.6 \pm 18.4$ & $11.6 \pm 14.5$ & $6.8 \pm 7.8 \dagger$ & $13.2 \pm 15.4$ & $13.2 \pm 26.4$ & $16.0 \pm 21.9$ & $14.7 \pm 16.7 \dagger$ & $26.3 \pm 27.3$ & $49.7 \pm 29.3$ & $76.6 \pm 36.4 \uparrow$ \\
\hline$\% \mathrm{BT} / \mathrm{LV}$ & $75.4 \pm 18.4$ & $26.7 \pm 46.2$ & $63.5 \pm 31.2$ & $39.7 \pm 42.0$ & $36.9 \pm 39.1$ & $32.8 \pm 30.1$ & $60.0 \pm 30.0$ & $31.1 \pm 54.0$ & $43.7 \pm 46.9$ & $39.0 \pm 39.4$ & $37.0 \pm 34.8$ & $76.3 \pm 45.5$ & $126.3 \pm 53.0$ \\
\hline $\begin{array}{l}\text { Dur. arousal } \\
(\min )\end{array}$ & $0.0 \pm 0.0$ & $1.4 \pm 1.7$ & $0.0 \pm 0.0$ & $0.0 \pm 0.0$ & $0.0 \pm 0.0$ & $0.0 \pm 0.0$ & $0.0 \pm 0.0$ & $0.0 \pm 0.0$ & $0.58 \pm 1.2$ & $0.0 \pm 0.0$ & $0.0 \pm 0.0$ & $22.3 \pm 28.6$ & $18.5 \pm 14.5 \ddagger$ \\
\hline $\begin{array}{l}\text { Long. ap. prd. } \\
\text { (min) }\end{array}$ & $34.6 \pm 19.7$ & $30.0 \pm 9.6$ & $23.0 \pm 14.1$ & $30.5 \pm 6.8$ & $33.2 \pm 12.9$ & $37.1 \pm 6.2$ & $29.5 \pm 13.4$ & $27.2 \pm 10.7$ & $30.1 \pm 14.6$ & $27.5 \pm 11.8$ & $25.6 \pm 13.3$ & $15.2 \pm 13.6$ & $11.3 \pm 14.0$ \\
\hline $\begin{array}{l}\text { Long. br. prd. } \\
\text { (min) }\end{array}$ & $21.2 \pm 7.7$ & $7.3 \pm 11.0$ & $10.5 \pm 14.6$ & $4.7 \pm 7.0 \S$ & $5.3 \pm 5.6 \S$ & $3.0 \pm 3.4 \|$ & $5.2 \pm 6.0 \|$ & $6.8 \pm 11.5$ & $7.3 \pm 8.4 \ddagger$ & $6.2 \pm 7.5 \S$ & $11.4 \pm 17.0$ & $37.02 \pm 33.0$ & $34.0 \pm 18.5$ \\
\hline $\mathrm{pH}$ & $7.30 \pm 0.04$ & $7.33 \pm 0.08$ & $7.31 \pm 0.01$ & $7.33 \pm 0.02$ & $7.31 \pm 0.01$ & $7.34 \pm 0.05$ & $7.34 \pm 0.04$ & $7.34 \pm 0.02$ & $7.33 \pm 0.03$ & $7.31 \pm 0.05$ & $7.31 \pm 0.06$ & $7.30 \pm 0.05$ & $7.25 \pm 0.05 \|$ \\
\hline $\mathrm{PaCO}_{2}(\mathrm{kPa})$ & $5.9 \pm 0.7$ & $5.1 \pm 0.7$ & $4.6 \pm 0.4 \S$ & $5.3 \pm 0.5$ & $5.2 \pm 0.5$ & $5.3 \pm 0.8$ & $5.2 \pm 0.5$ & $5.4 \pm 0.7$ & $5.1 \pm 0.4 \ddagger$ & $5.1 \pm 0.8 \dagger$ & $5.2 \pm 0.6 \dagger$ & & $6.2 \pm 1.0$ \\
\hline $\mathrm{PaO}_{2}(\mathrm{kPa})$ & $2.9 \pm 0.7$ & $3.0 \pm 1.1$ & $3.3 \pm 1.0$ & $3.0 \pm 1.0$ & $3.1 \pm 1.1$ & $3.2 \pm 0.9$ & $3.3 \pm 1.2$ & $3.7 \pm 1.8$ & $4.7 \pm 4.1$ & $3.1 \pm 1.0$ & $3.9 \pm 0.8$ & $8.6 \pm 7.1$ & $23.4 \pm 14.8 \S$ \\
\hline $\begin{array}{l}\mathrm{HCO}_{3} \\
\quad(\mathrm{mmol} / \mathrm{L})\end{array}$ & $21.3 \pm 1.7$ & $19.6 \pm 1.1$ & $17.6 \pm 4.2$ & $20.2 \pm 3.2$ & $19.7 \pm 4.4$ & $21.0 \pm 2.9$ & $20.7 \pm 1.4$ & $20.6 \pm 2.8$ & $18.3 \pm 2.5$ & $18.9 \pm 2.7 \S$ & $19.4 \pm 2.7$ & $19.6 \pm 2.7 \dagger$ & $19.9 \pm 2.3$ \\
\hline $\begin{array}{l}\mathrm{BD} / \mathrm{BE} \\
(\mathrm{mmol} / \mathrm{L})\end{array}$ & $-3.6 \pm 1.6$ & $-4.3 \pm 2.6$ & $-6.3 \pm 5.7$ & $-4.1 \pm 4.7$ & $-4.7 \pm 5.5$ & $-3.1 \pm 2.8$ & $-3.1 \pm 1.5$ & $-2.9 \pm 2.3$ & $-5.1 \pm 0.9$ & $-5.2 \pm 2.5 \ddagger$ & $-4.9 \pm 3.2 \dagger$ & $-5.0 \pm 2.5 \dagger$ & $-5.8 \pm 2.4 \dagger$ \\
\hline $\begin{array}{l}\text { Syst BP } \\
(\mathrm{mm} \mathrm{Hg})\end{array}$ & $67.8 \pm 11.1$ & $76.3 \pm 13.9$ & $78.0 \pm 14.7$ & $70.0 \pm 15.2$ & $72.3 \pm 13.1$ & $74.0 \pm 16.5$ & $72.8 \pm 17.5$ & $73.0 \pm 15.8$ & $73.0 \pm 16.9$ & $70.8 \pm 18.3$ & $74.2 \pm 13.6$ & $66.8 \pm 16.7 \ddagger$ & $66.4 \pm 15.2$ \\
\hline $\begin{array}{l}\text { Diast BP } \\
(\mathrm{mm} \mathrm{Hg})\end{array}$ & $44.5 \pm 10.8$ & $45.5 \pm 6.6$ & $51.5 \pm 9.0$ & $45.8 \pm 10.7$ & $43.8 \pm 11.0$ & $47.3 \pm 11.4$ & $47.8 \pm 13.0$ & $45.5 \pm 11.7$ & $47.5 \pm 12.5$ & $45.6 \pm 12.8$ & $50.0 \pm 10.2 \ddagger$ & $45.8 \pm 11.5$ & $41.2 \pm 9.0$ \\
\hline $\begin{array}{l}\text { Mean BP } \\
(\mathrm{mm} \mathrm{Hg})\end{array}$ & $52.2 \pm 10.0$ & $55.8 \pm 10.0$ & $60.3 \pm 10.9$ & $53.9 \pm 12.1$ & $53.3 \pm 11.5$ & $56.2 \pm 13.1$ & $56.1 \pm 14.4$ & $54.7 \pm 13.1$ & $56.0 \pm 13.9$ & $58.0 \pm 13.3$ & $57.1 \pm 12.5$ & $56.0 \pm 12.83$ & $52.5 \pm 10.3$ \\
\hline $\begin{array}{l}\text { Heart rate } \\
(\mathrm{bpm})\end{array}$ & $140.0 \pm 12.0$ & $146.0 \pm 17.0$ & $146.0 \pm 16.0$ & $145.0 \pm 13.0$ & $143.0 \pm 12.0$ & $144.0 \pm 14.0$ & $147.0 \pm 16.0$ & $132.0 \pm 25.0$ & $145.0 \pm 18.0$ & $138.0 \pm 10.0$ & $134.0 \pm 15.0$ & $144.0 \pm 28.0$ & $144.0 \pm 23.0$ \\
\hline
\end{tabular}

* Values are mean $\pm \mathrm{SD} . \% \mathrm{BT}$, percentage of breathing time; \% BT/LV, ratio of breathing time during LV-ECoG; Dur. arousal, duration of arousal; Long. ap. prd., longest apneic period; Long br. prd longest breathing period; BD/BE, base deficit/base excess; Syst BP, Systolic blood pressure; and Diast BP, Diastolic blood pressure.

$\dagger p \leq 0.05$.

$\ddagger p \leq 0.03$

$\S p \leq 0.02$.

$\| p \leq 0.01$. 

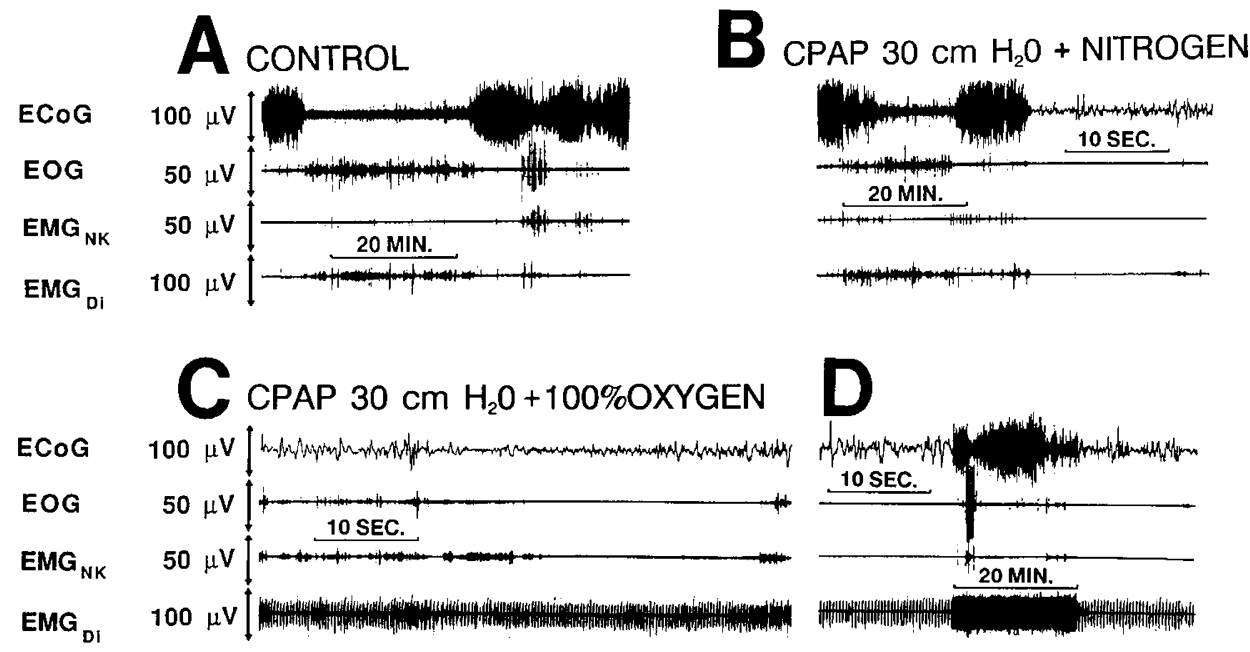

Fig. 2. Effects of lung distension at $139 \mathrm{~d}$ of gestation. Representative tracing showing the control period $(A)$ and the effects of lung distension with $0 \% \mathrm{O}_{2}(100 \%$ nitrogen $)(B)$ and with $100 \%$ oxygen $(C)$. The pattern of FBM was similar during the control period $(A)$ and during lung distension with nitrogen $(B)$. However, stronger and continuous FBM occurred during both LV-and HV-ECoG when oxygen concentration was changed to $100 \%(C)$ and $(D)$. The onset of continuous FBM coincided with the onset of arousal $(C)$.

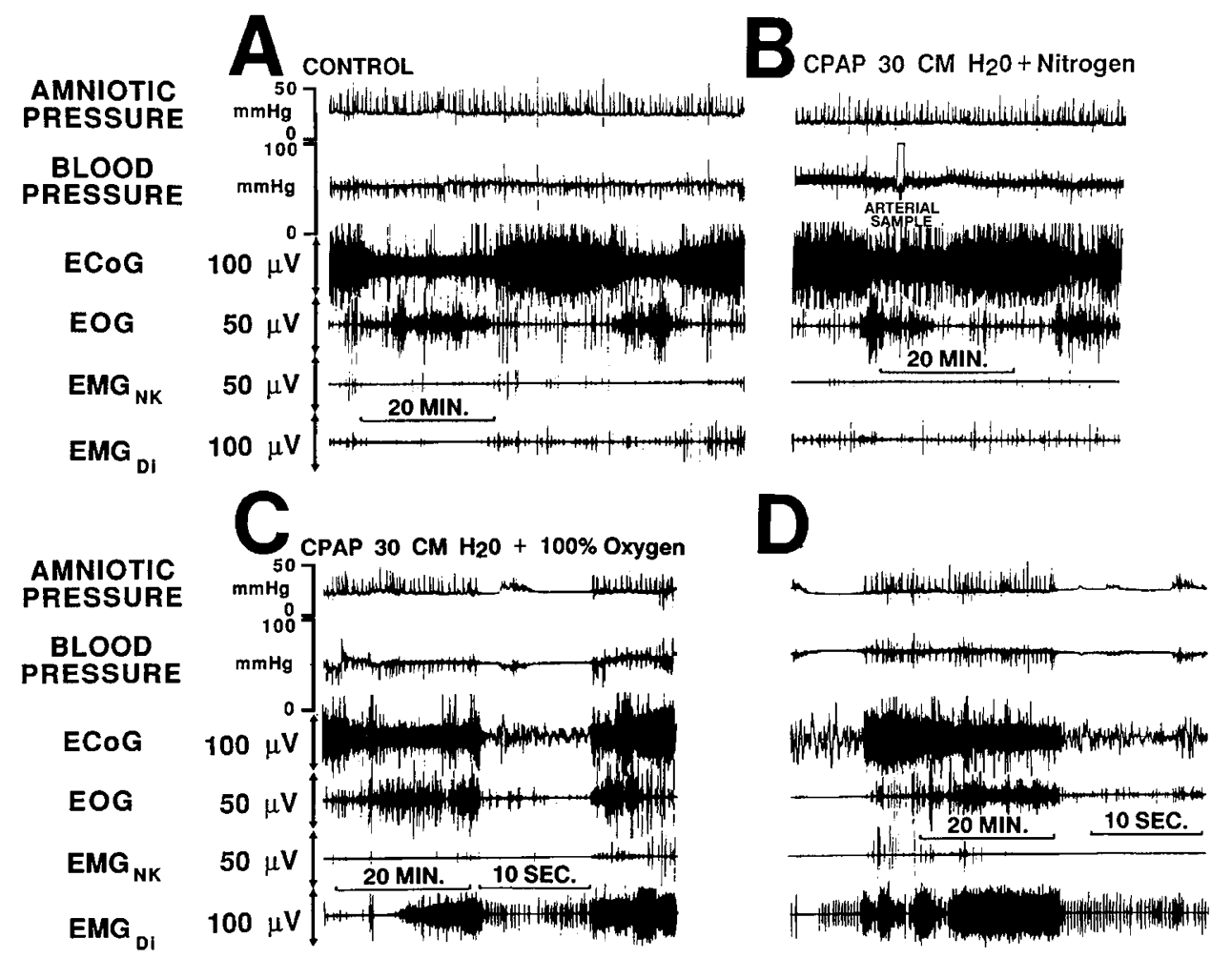

Fig. 3. Effects of lung distension during labor. Representative tracing showing the control and the effects of lung distension during spontaneous onset of labor at $142 \mathrm{~d}$ of gestation. During the control period $(A)$, no spontaneous breathing activity was present. Lung distension with $0 \% \mathrm{O}_{2}$ ( $100 \%$ nitrogen) at a CPAP of $30 \mathrm{~cm} \mathrm{H}_{2} \mathrm{O}$ did not induce breathing movements $(B)$; however, $100 \% \mathrm{O}_{2}$ induced breathing $(C)$, which continued during both LV- and HV-ECoG $(D)$.

but such stimulation of breathing has a latency period of 60 to $400 \mathrm{~min}$, depending on the agent used to produce metabolic acidosis $(32,33)$. The lag period in our studies was 0 to $30 \mathrm{~min}$, and, although the decrease in $\mathrm{pH}$ in our younger fetuses did not stimulate breathing, in the studies by Molteni et al. (32), stimulation of breathing by metabolic acidosis was independent of gestational age. Therefore, our results do not suggest that metabolic acidemia played a primary role in the induction of continuous FBM. In the present study, cardiovascular responses during experiments were not different from the control condition. Similar results have been reported previously $(9,26)$.

The incidence of total breathing time under control conditions was similar to that reported previously by several investigators $(2,5)$. However, the length of the single longest breathing epoch as well as the overall incidence of total breathing time was significantly decreased in response to lung distension with $\mathrm{N}_{2}$ at higher pressure in fetuses of greater than $134 \mathrm{~d}$ of gestation. This decrease in breathing might have been due to the stimulation of slowly adapting pulmonary stretch receptor-fiber-afferent systems, inasmuch as their activity during fetal life has been reported (34).

Because the onset of fetal arousal always coincides with the onset of continuous breathing, we cannot determine if there is a causal relationship between arousal and the onset of breathing 
or if a common modulator such as an increase in fetal $\mathrm{PaO}_{2}$ mediated both behavioral and breathing responses. Arousal is known to influence respiratory activity during adult as well as fetal life $(10,35)$. On the other hand, respiratory stimuli such as hypercapnia, hypoxia, airway occlusion, and bronchopulmonary irritation may induce arousal $(11,36)$. The threshold level for arousal is dependent on the prevailing sleep state (11). It is conceivable that bronchopulmonary irritation produced by high concentrations of inspired $\mathrm{O}_{2}$ or increased concentrations of prostaglandins in the pulmonary circulation might have led to arousal via rapidly adapting receptors or nonmyelinated $C$ fibers (37). The increased prostaglandins $I_{2}$ (prostacyclin) and prostaglandin $E_{2}$ concentrations might have resulted from either direct pulmonary mechanical effects of lung distension or from increased pulmonary blood flow due to the static distension of fetal lungs, respectively $(38,39)$. This mechanism appears to be unlikely, inasmuch as prostaglandins, especially prostaglandin $E_{1}$ and $E_{2}$, are not only metabolized rapidly by the lungs, but are also known to suppress fetal and neonatal breathing (39-41). However, to the best of our knowledge, effects of prostaglandin $\mathrm{I}_{2}$ (prostacyclin) on FBM have not been studied. In a wellexecuted study, Adamson et al. (42) induced continuous fetal breathing by occluding the umbilical cord and providing the fetus with a mixture of $50 \% \mathrm{O}_{2}$ in air at a CPAP of $3 \mathrm{~mm} \mathrm{Hg}$. Umbilical cord release resulted in a significant decrease in breathing activity, suggesting that the response might have been mediated by a hormone or a neurotransmitter produced by the placenta. They also observed the invariable presence of arousal at the onset of continuous breathing movements (42). Similar breathing and behavioral changes have been reported in human as well as sheep fetuses at the time of birth $(43,44)$. Although arousal was always present at the initiation of continuous breathing, breathing, once initiated, continued during all sleep states.

Several studies, including our present study, have shown that fetal breathing movements decrease 2 to $3 \mathrm{~d}$ before labor and almost cease during the active stage of labor $(16,45)$. The possible mechanisms for this decrease in breathing have been discussed in detail by Berger et al. (16). Nathanielsz et al. (46) have reported that episodic increases in myometrial tone, known as contractures, occurred at a rate of approximately $1 / \mathrm{h}$ and were associated with a shift from fetal breathing activity to quiescence. These episodic contractures may be associated with the decreased cotyledonary blood flow, leading to a decrease in fetal $\mathrm{PaO}_{2}$. Considering this mechanism, one would expect a more profound decrease in fetal $\mathrm{PaO}_{2}$ during active labor that could account for complete fetal apnea; however, in our studies we could oxygenate the fetus in labor, thereby alleviating hypoxemia and inducing breathing movements. However, during the final hours of labor, we were unable to oxygenate the fetus and, consequently, we did not observe any change in breathing or behavioral responses.

In summary, we have shown that fetal maturity, an increase in $\mathrm{PaO}_{2}$, and a change in state from quiet sleep toward arousal are necessary conditions for the induction of continuous FBM. Furthermore, FBM can be stimulated during labor during both LV- and HV-ECoG. The underlying mechanisms of these new and fascinating responses remain unknown and warrant further studies.

Acknowledgments. The authors thank Dr. Tak Fung for painstaking statistical analysis, Naomi Anderson for editorial comments, and Michelle Cavanaugh for excellent secretarial support. We are especially indebted to Dr. James E. Fewell for providing thoughtful suggestions during these experiments.

\section{REFERENCES}

1. Dawes GS, Fox HE, Leduc BM, Liggins GC, Richards RT 1972 Respiratory movements and rapid eye movement sleep in the fetal lamb. J Physiol (Lond) 220:1 19-143

2. Patrick J 1982 Fetal breathing movements. Clin Obstet Gynecol 25:787-803

3. Boddy K, Dawes GS, Fisher R, Pinter S, Robinson JS 1974 Foetal respiratory movements, electrocortical and cardiovascular response to hypoxemia and hypercapnia in sheep. J Physiol (Lond) 243:599-618

4. Koos BJ, Sameshima H, Power GG 1987 Fetal breathing, sleep states and cardiovascular responses to graded hypoxia in sheep. J Appl Physiol 62:10331039

5. Jansen AH, Chernick V 1983 Development of Respiratory Control. Physiol Rev 63:437-483

6. Hasan SU, Lee DS, Gibson DA, Nowaczyk BJ, Cates DB, Sitar DS, Pinsky C, Rigatto H 1988 Effect of morphine on breathing and behavior in fetal sheep. J Appl Physiol 64:2058-2065

7. Kitterman JA, Liggins GC, Clements JA, Tooley WH 1979 Stimulation of breathing movements in fetal sheep by inhibitors of prostaglandin synthesis. J Dev Physiol 1:453-466

8. Sheldon RE, Toubas L 1984 Morphine stimulates rapid, regular, deep, and sustained breathing efforts in fetal lambs. J Appl Physiol 57:40-43

9. Baier RJ, Hasan SU, Cates D, Hooper DA, Nowaczyk B, Rigatto H 1990 Effect of various concentrations of oxygen and umbilical cord occlusion on fetal breathing and behavior in sheep. J Appl Physiol 68:1597-1604

10. Ioffe S, Jansen AH, Russell BH, Chernick V 1980 Sleep, wakefulness and the monosynaptic reflex in fetal and newborn lambs. Pflugers Arch 388:149157

11. Phillipson EA, Bowes G 1986 Control of breathing during sleep. In: Fishman AP (ed) Handbook of Physiology; Section 3: The Respiratory System; Vol 2: Control of Breathing, Pt 2. American Physiological Society, Bethesda, MD, pp 649-683

12. Walker DW 1988 Effects of increased core temperature on breathing movements and electrocortical activity in fetal sheep. J Dev Physiol 10:513-523

13. Gluckman PD, Gunn TRG, Johnston BM 1983 The effect of cooling on breathing and shivering in unanesthetized fetal sheep in utero. J Physiol (Lond) 343:495-506

14. Dixon WJ 1988 BMDP Statistical Software, Vol 1 and 2. University of California Press, Berkeley, CA

15. Winer BJ 1971 Statistical Principles in Experimental Design. McGraw-Hill, New York, pp 514-538

16. Berger PJ, Walker AM, Horne R, Brodecky V, Wilkinson $\mathrm{MH}$, Wilson $\mathrm{F}$, Maloney JE 1986 Phasic respiratory activity in the fetal lamb during late gestation and labour. Respir Physiol 65:55-68

17. Johnston BM, Gluckman PD 1989 Lateral pontine lesions affect central chemosensitivity in unanesthetized fetal lambs. J Appl Physiol 67:11131118

18. Dawes GS, Gardiner WM, Johnson BM, Walker DW 1983 Breathing in fetal lambs: the effects of brain stem section. J Physiol 335:535-553

19. Hasan SU, Bamford O, Hawkins R, Gibson D, Nowaczyk B, Cates D, Rigatto $\mathrm{H} 1990$ The effect of midbrain section on the breathing response to morphine in the fetal sheep. J Dev Physiol 13:147-155

20. Henderson-Smart DJ, Pettigrew AG, Campbell DJ 1983 Clinical apnea and brainstem neural function in preterm infants. N Engl J Med 308:353-357

21. Assali NS, Kirschbaum TH, Dilts PV 1968 Effects of hyperbaric oxygen on uteroplacental and fetal circulation. Circ Res 22:573-588

22. Morin FD, Egan EA, Ferguson W, Lundgren CEG 1988 Development of pulmonary vascular response to oxygen. Am J Physiol 254:H542-H546

23. Willis DM, Anderson DF, Thornburg KL, Faber JJ 1985 Alteration of arterial gas composition by positive pressure ventilation in the unanesthetized fetal lamb in utero. Biol Neonate 47:295-304

24. Iwamoto HS, Teitel D, Rudolph A 1987 Effects of birth-related events on blood flow distribution. Pediatr Res 22:634-640

25. Teitel DF, Iwamoto HS, Rudolph AM 1990 Changes in the pulmonary circulation during birth-related events. Pediatr Res 27:372-378

26. Blanco CE, Martin CB, Rankin J, Landauer M, Phernetton T 1988 Changes in fetal organ flow during intrauterine mechanical ventilation with or without oxygen. J Dev Physiol 10:53-62

27. Ganong WF 1985 Review of Medical Physiology. Lange Medical Publications, Los Altos, CA, pp 496-513

28. Fewell JE, Norton Jr JB 1980 Continuous positive airway pressure impairs renal function in newborn goats. Pediatr Res 14:1132-1134

29. Fewell JE, Abendschein DR, Carlson CJ, Murray JE, Rapaport E 1980 Continuous positive-pressure ventilation decreases right and left ventricular enddiastolic volumes in the dog. Circ Res 46:125-132

30. Towell ME, Johnson J, Smedstad K, Andrew M, Vu T-L 1984 Fetal blood and tissue $\mathrm{PO}_{2}$ during maternal oxygen breathing. J Dev Physiol 6:177-185

31. Lewis BV 1968 The response of isolated sheep and human umbilical arteries to oxygen and drugs. J Obstet Gynaecol Br Commonw 75:87-91

32. Molteni RA, Melmed MH, Sheldon RE, Jones MD, Meschia G 1980 Induction of fetal breathing by metabolic acidemia and its effect on blood flow to the respiratory muscles. Am J Obstet Gynecol 136:609-620

33. Hohimer AR, Bissonnette JM 1981 Effect of metabolic acidosis on fetal breathing movements in utero. Respir Physiol 43:99-106

34. Maloney JE, Adamson TM, Brodecky V, Dowling MH, Ritchie BC 1975 Modification of respiratory center output in the unanesthetized fetal sheep in utero. J Appl Physiol 39:552

35. Phillipson EA, Murphy E, Kozar LF 1976 Regulation of respiration in sleeping dogs. J Appl Physiol 40:688-693

36. Sullivan CE, Kozar LF, Murphy E, Phillipson EA 1979 Arousal, ventilatory, and airway responses to bronchopulmonary stimulation in sleeping dogs. $\mathrm{J}$ Appl Physiol 47:17-25

37. Coleridge HM, Coleridge JCG 1986 Reflexes evoked from tracheobronchial tree and lungs. In: Fishman AP (ed) Handbook of Physiology; Section 3: 
The Respiratory System; Vol 2: Control of Breathing, Pt 2. American Physiological Society, Bethesda, MD, p 395-429

38. Colebatch HJH, Dawes GS, Goodwin JW, Nadeau RA 1965 The nervous control of the circulation in the foetal and newly expanded lungs of the lamb. J Physiol 178:544-562

39. Leffler CW, Hessler JR, Green RS 1984 The onset of breathing at birth stimulates pulmonary vascular prostacyclin synthesis. Pediatr Res 18:938942

40. Kitterman JA, Liggins GC, Fewell JE, Tooley WH 1983 Inhibition of breathing movements in fetal sheep by prostaglandins. J Appl Physiol 54:687-692

41. Lewis AB, Freed MD, Heymann MA, Roehl SL, Kensey RC 1981 Side effects of therapy with prostaglandin $E_{1}$ in infants with critical congenital heart disease. Circulation 64:893-898
42. Adamson SL, Richardson BS, Homan J 1987 Initiation of pulmonary gas exchange by fetal sheep in utero. J Appl Physiol 62:989-998

43. Desmond MM, Franklin RR, Vallbona C, Hill RM, Plumb R, Arnold H, Watts J 1963 The clinical behavior of the newly born. J Pediatr 62:307-325

44. Harned Jr HS, Rowshaw G, MacKinney LG, Sugioka K 1964 Relationship of $\mathrm{PO}_{2}, \mathrm{PCO}_{2}$ and $\mathrm{pH}$ to onset of breathing of the term lamb as studied by a flow-through cuvette electrode assembly. Pediatrics 33:672-681

45. Richardson B, Natale R, Patrick J 1979 Human fetal breathing activity during induced labour at term. Am J Obstet Gynecol 133:247-255

46. Nathanielsz PW, Bailey A, Poore ER, Thorburn GD, Harding R 1980 The relationship between myometrial activity and sleep state and breathing in fetal sheep throughout the last third of gestation. Am J Obstet Gynecol 138:653-659 